\title{
Large-scale processes modulating the frequency of typhoons affecting Taiwan during 1900-1945
}

\author{
Pei-Hua Tan ${ }^{1, *}$, Jien-Yi Tu ${ }^{2}$, and Mei-Yun Tsai ${ }^{3}$ \\ ${ }^{1}$ Department of Applied History, National Chiayi University, Chiayi City, Taiwan \\ ${ }^{2}$ Department of Geography, National Changhua University of Education, Changhua County, Taiwan \\ ${ }^{3}$ Department of Maritime Information and Technology, National Kaohsiung University of Science and Technology, \\ Kaohsiung City, Taiwan
}

\begin{abstract}
Article history:
Received 23 July 2021

Revised 14 November 2021

Accepted 29 November 2021

Keywords:

Interannual variability, Typhoon track, Cold period, Presatellite era, Intraseasonal oscillation

\section{Citation:}

Tan, P.-H., J.-Y. Tu, and M.-Y. Tsai, 2021: Large-scale processes modulating the frequency of typhoons affecting Taiwan during 1900-1945. Terr. Atmos. Ocean. Sci., 32, 1197-1213, doi: 10.3319/ TAO.2021.11.29.01
\end{abstract}

\begin{abstract}
The typhoons affecting Taiwan during 1900-1945 are defined as those with a low-pressure center making a landfall in Taiwan or moving near Taiwan and included in disaster reports. The annual and monthly numbers of typhoons were lower during 1900-1945 than during 1970-2015, which might be attributed to the colder environment, a weakened western North Pacific subtropical high with the eastward retreat and lack of satellite detection techniques during 1900-1945. However, the monthly percentages of typhoons were comparable in the high-frequency months of July-September during the two periods. In contrast to the warm period, the cold period had fewer total typhoon numbers but more concentrated occurrence during May-October. During 1900-1945, an interannual variability of the typhoon frequency affecting Taiwan was observed. During the typhoon-more (typhoon-less) years, the significant sea surface temperature patterns were dominated by warm (cold) anomalies elongating the tropical central-eastern Pacific with a maximum center in the central Pacific and cold (warm) anomalies over the tropical western Pacific. The anticyclonic (cyclonic) circulation around Taiwan that responds to a divergent (convergent) center in the Maritime Continents tended to provide a favorable (unfavorable) steering flow to force typhoons over the east of the Philippines moving westward/northwestward (eastward) toward (away from) Taiwan. The modulations of intraseasonal oscillations on typhoon movements under the westward/northwestward and northward tracks of typhoons affecting Taiwan exerted a positive but different effect on steering the typhoon toward or near Taiwan.
\end{abstract}

\section{INTRODUCTION}

Typhoons accompanied with strong winds and heavy precipitation are one of the most dangerous types of natural hazards globally (Wang and Lin 2002; Chen and Chen 2011; Tu and Chen 2019). Typhoons tend to form at a warm ocean temperature of minimum $26.5^{\circ} \mathrm{C}$ threshold and in favorable conditions such as during sufficient vorticity and convergence, decreased atmospheric stability, sufficient Coriolis force, high lower-tropospheric relative humidity, and low vertical wind shear (Gray 1968, 1998; Lee et al. 1989; DeMaria et al. 2001; Emanuel 2008; McTaggartCowan et al. 2015).

\footnotetext{
* Corresponding author

E-mail:tan@mail.ncyu.edu.tw
}

Among global oceanic basins, tropical cyclone activity is the most active over the western North Pacific and the surrounding South China Sea. In the western North Pacific, tropical cyclone movements are divided into seven major tracks: four recurve tracks moving northward toward the western North Pacific, one northwestward track from the tropical western North Pacific toward East Asia, one westward track toward the South China Sea, and one track with genesis and movements inside the South China Sea (Camargo et al. 2007; Chu et al. 2010; Kim et al. 2012; Tan et al. 2019).

From July to October, 50\%-60\% of total rainfall was accounted for by typhoons in the regions of $18^{\circ} \mathrm{N}$ and $26^{\circ} \mathrm{N}$ (Kubota and Wang 2009). In Taiwan, $47.5 \%$ of total rainfall 
from July to September (Chen et al. 2010) and 27\% of total rainfall in October could be attributed to typhoons (Chen et al. 2013). In particular, in eastern Taiwan, more than $60 \%$ of total rainfall from July to October was contributed by typhoons (Kubota and Wang 2009). Therefore, typhooninduced rainfall is a crucial water source in Taiwan (Tsou et al. 2016). The absence of or the occurrence of fewer typhoons than normal through or around Taiwan may have substantially affected economic, social, industrial, agricultural, and household water usage.

Typhoon tracks are strongly determined by genesis locations and steering flows (Wu and Wang 2004). The western North Pacific subtropical high provides an important source for steering flows of typhoon tracks across the western North Pacific region (Ho et al. 2004; Wu et al. 2005; Tu et al. 2009; Chu et al. 2012; Wang and Chen 2018). El Niño-Southern Oscillation (ENSO) exerts a considerable impact on the typhoon genesis locations in the western North Pacific and subsequent moving tracks.

The monsoon trough tends to expand eastward and have an eastward movement in the typhoon genesis location during El Niño years (Lander 1994; Chia and Ropelewski 2002; Zhan et al. 2011; Bell et al. 2014). The genesis frequency of tropical cyclones increases (decreases) in the southeastern (northwestern) quadrant of the western North Pacific due to cyclonic vorticity (upper-level convergence) anomalies (Wang and Chan 2002; Kim et al. 2011). As the genesis locations of tropical cyclones shift eastwards, tropical cyclones have more time over oceans before making a landfall, and thus normally live longer and gain more energy to enhance their intensity (Camargo and Sobel 2005; Kim et al. 2013). Due to the eastward expansion of monsoon trough, tropical easterlies weaken and exert a negative impact on the westward movements of tropical cyclones, therefore tropical cyclones have a longer period to experience beta effects and thus increase the chance of northward recurring movements (Wang and Chan 2002; Zhao et al. 2011; Colbert et al. 2015). Typhoons making a landfall in Japan and Korea along the northward recurring typhoon tracks are shown to have a higher frequency in the early summer of El Niño years than in La Niña years (Fudeyasu et al. 2006).

The propagation of intraseasonal oscillations (ISOs) modulates the tropical cyclone movement in the western North Pacific (Liebmann et al. 1994; Ko and Hsu 2009; Li and Zhou 2013; Chen et al. 2018) and South China Sea (Tan et al. 2019; Chen et al. 2020). In the western North Pacific, Ko and Hsu (2009) demonstrated that in the 30-80-day ISO westerly phase, the 7-30-day submonthly wave pattern was better organized and typhoons were clustered near the 7-30day cyclonic circulation during their genesis and propagation. On the other hand, the wave pattern and typhoons were weak and poorly organized in the ISO easterly phase. These results imply that both typhoon movement and propaga- tions of submonthly anomalies are effectively modulated by the 30-80-day ISO. Chen et al. (2018) demonstrated that summer typhoons tend to cluster around the center of a 10-24-day cyclonic anomaly and follow its northwestward propagation from the tropical western North Pacific toward the region near Taiwan. These typhoon movements are subject to favorable background conditions provided by a northwest-southeasterly extending 30-60-day cyclonic anomaly. Chen et al. (2020) analyzes ISO modulation on movements of typhoons formed over South China Sea. For typhoons with either the northward, northwestward, or northeastward tracks, they tend to follow the propagation of the 10-24-day cyclonic anomaly and move along different tracks. The above movement comes under the influence of favorable environments in terms of moisture convergence provided by 30-60-day cyclonic anomalies distributing along typhoon tracks.

Entrance tropical cyclones are defined as initially form in the western North Pacific and later move into the aimed region. Tan et al. (2019) examined the modulation processes of 30-60-day ISO on entrance tropical cyclones in the South China Sea and found four types of asymmetric relationships with ENSO: La Niña-more, La Niña-less, El Niño-more, and El Niño-less. ENSO provided a favorable environment for La Niña-more types but not for the other three types; however, 30-60-day ISO assisted La Niña-more, El Niñomore, and El Niño-less types but not the La Niña-less type.

The aforementioned studies have mainly focused on the satellite era after 1960. However, limited typhoon studies were conducted during 1900-1945, which refers to the presatellite era and a colder period than the late $20^{\text {th }}$ century. A major concern is the uncertainty of typhoon data, such as typhoon tracks, resulting from the lack of satellite data during 1900-1945. Over the past few decades, the Taiwan Central Weather Bureau (TCWB) has made considerable efforts to reconstruct the best tracks of typhoons that affected Taiwan during 1897-1948 by performing a comprehensive data analysis of weather maps and typhoon tracks collected from Hong Kong Royal Observatory, Shanghai Typhoon Research Institute, and Japan Meteorological Agency and the hourly measurements of meteorological stations in Taiwan and nearby islands under the Japanese government (Chin 1958; Hsu 1973; Wang 1992; Shieh et al. 1998). The best typhoon tracking data reconstructed by the TCWB were used to examine the modulating effect of ISOs on typhoon tracks affecting Taiwan. An interannual variability of the frequency of typhoons affecting Taiwan was observed during this period, and typhoon-more and typhoon-less years could be identified. The state-of-theart $20^{\text {th }}$ Century Reanalysis V2 data (Compo et al. 2011), validated by meteorological observations, were used in the analysis of large-scale processes associated with the frequency of typhoons affecting Taiwan.

In this study, we considered the cold period from 1900 
to 1945 which is a presatellite era, to investigate typhoon statistics and climatology during 1900-1945 and 19702015 (section 3.1), modulatory processes in typhoon-more and typhoon-less years during 1900-1945 (section 3.2), ISO modulations on typhoon movements during 1900-1945 (section 3.3), and the associated discussion. Conclusions are drawn at the end of this paper.

\section{DATA}

\subsection{Frequency of Typhoons Affecting Taiwan During 1900-1945}

The annual number of typhoons affecting Taiwan during 1900-1945 can be obtained from the book "Tropical cyclone tracks over Taiwan from 1897 to 1996 and their applications" published by the TCWB (Shieh et al. 1998). The typhoon affecting Taiwan was defined as the one with a low-pressure typhoon center that made a landfall over Taiwan or moved near Taiwan and was included in disaster reports. The typhoon during this period was recorded in the book to have the maximum sustained wind speed equal to or greater than 34 knots.

\subsection{Digitalized Typhoon Tracks}

Because the period from 1900 to 1945 refers to a presatellite era, no digital data regarding typhoon tracks are available. To address this limitation, over the past few decades, the TCWB has reconstructed the best tracks of typhoons affecting Taiwan during 1897-1948 by performing a comprehensive data analysis of weather maps and typhoon tracks collected from all nearby meteorological institutions from Hong Kong, Shanghai, and Japan and the hourly measurements of meteorological stations in Taiwan and nearby islands under the Japanese rule (Chin 1958; Hsu 1973; Wang 1992; Shieh et al. 1998). Thus, the position of the low-pressure typhoon center can be retrieved and digitalized from hourly best typhoon tracking data reconstructed by the TCWB for each typhoon event. Because the typhoon track map covers only the region of $19^{\circ} \mathrm{N}-29^{\circ} \mathrm{N}$ and $115^{\circ} \mathrm{E}-131^{\circ} \mathrm{E}$, the best typhoon track could not be retrieved beyond this region.

\subsection{Large-Scale Circulation Data}

To represent large-scale process associated with typhoon-more and typhoon-less years, the daily and monthly $20^{\text {th }}$ Century Reanalysis V2 data from National Oceanic and Atmospheric Administration (NOAA)/Earth System Research Laboratories (ESRL)/Physical Sciences Laboratory (PSL) (Compo et al. 2011; https://psl.noaa.gov/data/gridded/data.20thC ReanV2.html) were used. The $20^{\text {th }}$ Century Reanalysis V2 contains objectively analyzed 4-dimensional weather maps and has a temporal resolution of 6-hourly, daily, and monthly average data from January 1,1871 , to December 31, 2012, and a spatial resolution of $2.0^{\circ}$ latitude $\times 2.0^{\circ}$ longitude. The analyzed variables include the 850 $\mathrm{hPa}$ velocity potential, streamfunction, relative vorticity, 700-hPa relative humidity, $500-\mathrm{hPa}$ omega (vertical velocity), and wind, and vertical wind shear is defined as a zonal wind of $200 \mathrm{hPa}$ minus that of $850 \mathrm{hPa}$.

The monthly extended reconstruction SST (ERSST) version 5 data were used to illustrate the interannual variability of SST over the Pacific. The monthly and globally averaged ERSST version 5 anomaly comprises the extended data from 1854 to 2016 compared with version 4 .

\subsection{0-60 Days of ISOs}

ISOs are mainly composed of two components in the frequency bands of 10-24 and 30-60 days (Hartmann et al. 1992; Chen and Chen 1995; Chen et al. 2000; Ding 2007). The ISO-related studies discussed in the Introduction (Ko and Hsu 2009; Chen et al. 2018, 2020) reveal two salient features associated with ISO modulations on typhoon movements: (1) typhoons tend to cluster around the 10-24day/submonthly cyclonic anomaly to exhibit a coherent moving course along different typhoon tracks; (2) typhoon movements and propagations of the 10-24-day/submonthly cyclonic anomalies are both facilitated and thus modulated by the longer-lasting favorable background environments provided by the 30-60-day ISO. Thus, the analysis of 3060-day ISO should be sufficient to illustrate ISO's steering effect on typhoon movement. In this study, 30-60-day streamfunction at $850 \mathrm{hPa}$ from daily $20^{\text {th }}$ century R2 data was employed and the daily digital typhoon tracks were reconstructed from the TCWB (Shieh et al. 1998).

\section{RESULTS AND DISCUSSION}

\subsection{Typhoon Statistics and Climatology During 1900-1945 and 1970-2015}

The periods of 1900-1945 and 1970-2015 were chosen to compare typhoon statistics and climatology associated with typhoons affecting Taiwan. Globally-averaged surface air temperature anomalies (not shown) during 1946-1969 did not change uniformly positive or negative and the first weather satellite TIROS-1 was not launched until 1960. Thus, the period of 1946-1969 was not considered due to the lack of a consistent sign of temperature change and also a consistent method to observe typhoons.

The monthly average number of typhoons affecting Taiwan from April to December was lower in 1900-1945 (red bars in Fig. 1a) than in 1970-2015 (blue bars in Fig. 1a). No typhoon affecting Taiwan occur from January to March. The total number of typhoons from April to December was 170 during 1900-1945 and 287 during 1970-2015.

A high typhoon frequency occurred during the three 


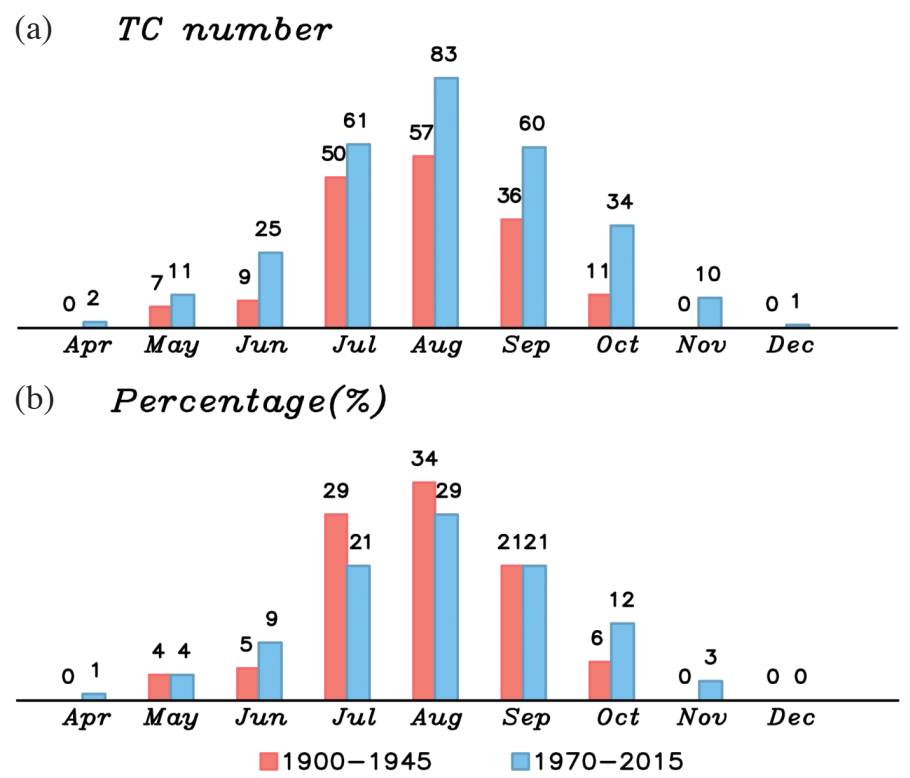

Fig. 1. The monthly average (a) number and (b) percentage (\%) of typhoons affecting Taiwan from April to December during 1900-1945 (red color) and 1970-2015 (blue color).

months of July, August, and September with frequencies of 50 (61), 57 (83), and 36 (60), respectively, in 1900-1945 (1970-2015). The typhoon numbers were 7-11 in May, June, and October and 0 in April, November, and December during 1900-1945. In contrast, the typhoon numbers during 1970-2015 were all higher in these months: 11-34 in May, June, and October and 1-10 in April, November, and December. October and June had a 1-month difference, respectively, with the high frequency months of September and July. However, typhoons in both periods had a higher frequency in October than in June, implying the lag effects of ocean memory (Bruneau et al. 2020). No typhoon occurred in April, November, and December during 1900-1945; however, 13 typhoons occurred in April, November, and December during 1970-2015, implying the more suitable environment for typhoon development during 1970-2015 (warm period) than during 1900-1945 (cold period). The typhoons in the western North Pacific during the less active months (from December to February) of the warm period are also called as Christmas typhoons, representing their effect on Christmas holidays (Basconcillo and Moon 2021). Note that the typhoon numbers during 1900-1945 were obtained from Shieh et al. (1998) developed by Taiwan Central Weather Bureau, different from those after 1960 from the digitalized satellite-supported best-track databases such as JTWC, RSMC, and IBTRACS. Therefore, the typhoon numbers during 1900-1945 and 1970-2015 are not suitable to put together for the analysis of long-term trend or multidecadal variability.

The monthly average percentage of typhoons affecting Taiwan from April to December during 1900-1945 (red bars in Fig. 1b) indicated that a high percentage of ty- phoons occurred during the three months of July, August, and September $(29 \%, 34 \%$, and $21 \%$, respectively). The typhoon percentage ranged from $4 \%$ to $6 \%$ for May, June, and October and $0 \%$ for April, November, and December. The monthly average percentage of typhoons affecting Taiwan during 1970-2015 (blue bars in Fig. 1b) indicated that a high percentage of typhoons occurred during the three months of July, August, and September with percentages of $21 \%, 29 \%$, and $21 \%$, respectively. The typhoon percentage ranged from $4 \%$ to $12 \%$ in May, June, and October and from $0 \%$ to $3 \%$ in April, November, and December. In July-September, the total number of typhoons varied largely, with 143 during 1900-1945 and 204 during 1970-2015; however, the total percentage of typhoon frequency was comparable, with $84 \%$ during $1900-1945$ and $71 \%$ during 1970-2015, implying a more concentrated occurrence of typhoons in July-September and less diversified distribution among other months in the cold period than in the warm period. Higher typhoon numbers affecting Taiwan during 1970-2015 than during 1900-1945 might be associated with several mechanisms such as warmer ocean temperature, stronger western North Pacific subtropical high with westward expansion, ISO modulations and better detection techniques during 1970-2015 and these issues were further examined as follows.

In the 1900-1945 period, the climatological means of sea surface temperature (SST), 850-hPa velocity potential (X850), and 850-hPa streamfunction (S850) in July-September revealed the presence of a warm SST center over tropical western Pacific (Fig. 2a), an elongated convergence center from southeastern China to the east of Philippine Islands (Fig. 2b), two anticyclonic centers in the subtropical 


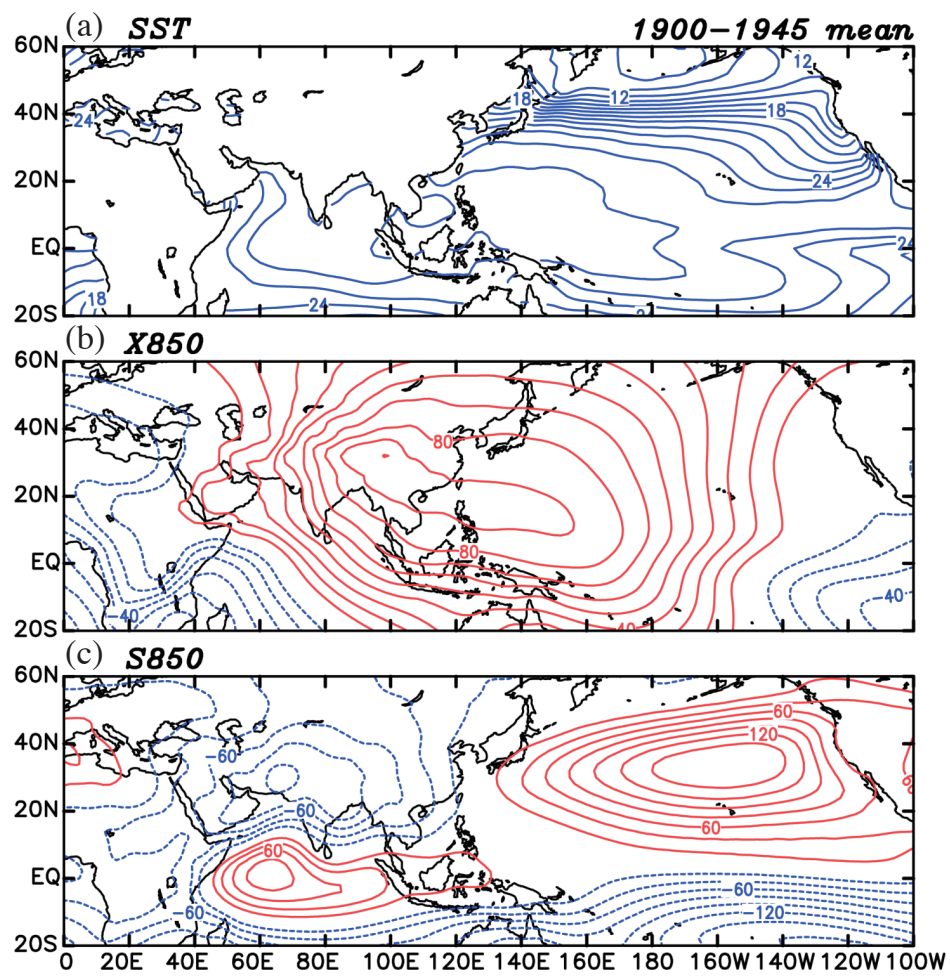

Fig. 2. The climatological means of (a) sea surface temperature (SST), (b) 850-hPa velocity potential (X850), and (c) 850-hPa streamfunction (S850) in July-September of 1900-1945. Contour intervals are $1.5^{\circ} \mathrm{C}$ in (a), $10 \times 10^{5} \mathrm{~m}^{2} \mathrm{~s}^{-1}$ in (b), and $20 \times 10^{5} \mathrm{~m}^{2} \mathrm{~s}^{-1}$ in (c). The zero contours are suppressed.

North Pacific and the tropical Indian Ocean, and two cyclonic centers in the southern Eurasia and the subtropical North Pacific (Fig. 2c), respectively. The climatological means of SST (Fig. 3a), X850 (Fig. 3b), and S850 (Fig. 3c) in July-September in 1970-2015 revealed similar patterns but with a stronger intensity than those in 1900-1945. The location and strength of western North Pacific subtropical high is one of the important factors in determining the frequency of typhoons affecting Taiwan. The intensified western North Pacific subtropical high with a westward expansion contributed the frequency of typhoons affecting Taiwan (Ho et al. 2004; Wu et al. 2005) during 1970-2015 (Fig. 3c) than during 1900-1945 (Fig. 2c).

The differences of SST, X850, and S850 in July-September in 1900-1945 minus those in 1970-2015 are shown in Fig. 4. Differences or composite anomalies with significance at the 0.10 level obtained using Student's $t$ test are shaded. The significant SST patterns featured dominant cold differences almost over all the Pacific Ocean and Indian Ocean with maximum cold differences of $-0.8^{\circ} \mathrm{C}$ in the subtropical central Pacific (Fig. 4a). Warmer SST during 1970-2015 than during 1900-1945 with a maximum difference of $0.4^{\circ} \mathrm{C}$ to the east of Philippines provided a suitable environment for typhoon genesis and development (Fig. 4a). The increase of total typhoon genesis numbers in the western North Pacific might not guarantee the increase of typhoon numbers affecting Taiwan; however, it could provide help in increasing the possibility of the typhoon numbers affecting Taiwan.

In response to SST differences, X850 differences exhibited a divergent center (negative values) in the Bay of Bengal and a convergence center (positive values) around $140^{\circ} \mathrm{W}$ in the tropical eastern Pacific (Fig. 4b). Through the response of a Matsuno-Gill type (Matsuno 1966; Gill 1980) to tropical forcing described by X850 differences, S850 differences (Fig. 4c) revealed a large cyclonic circulation (negative values) with three minor divided cyclonic centers around Maritime Continents to the north of $10^{\circ} \mathrm{S}$ and an anticyclonic circulation (positive values) to the south of $10^{\circ} \mathrm{S}$. One of the divided cyclonic circulations close to Taiwan tended to drive typhoons over the east of the Philippines to have westward or northward movement toward Taiwan. X850 differences (Fig. 4b) were dominated by a divergence circulation over Eurasia, implying a weaker convergence circulation during 1900-1945 than during 1970-2015. Similarly, compared to the 2-meter air temperature field (not shown) of 1970-2015, that of 1900-1945 exhibited a colder land and slightly cold ocean in Asia which resulted in a lower land-sea contrast and corresponding weaker monsoon and convergence. Thus, the land-sea contrast should play a role in shaping the complicated pattern of S850 differences (Fig. 4c). 

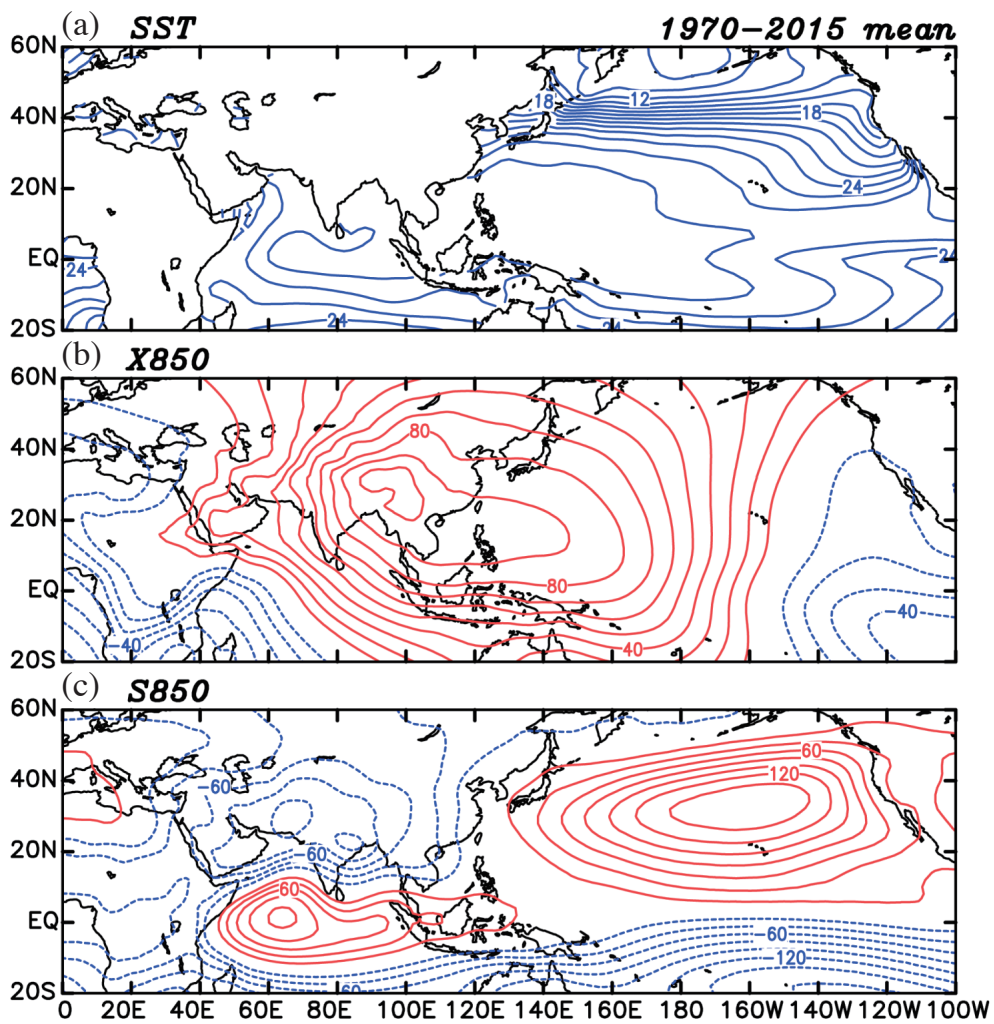

Fig. 3. As in Fig. 2, except for the climatological means of (a) SST, (b) 850-hPa velocity potential, and (c) 850-hPa streamfunction in July-September of 1970-2015.
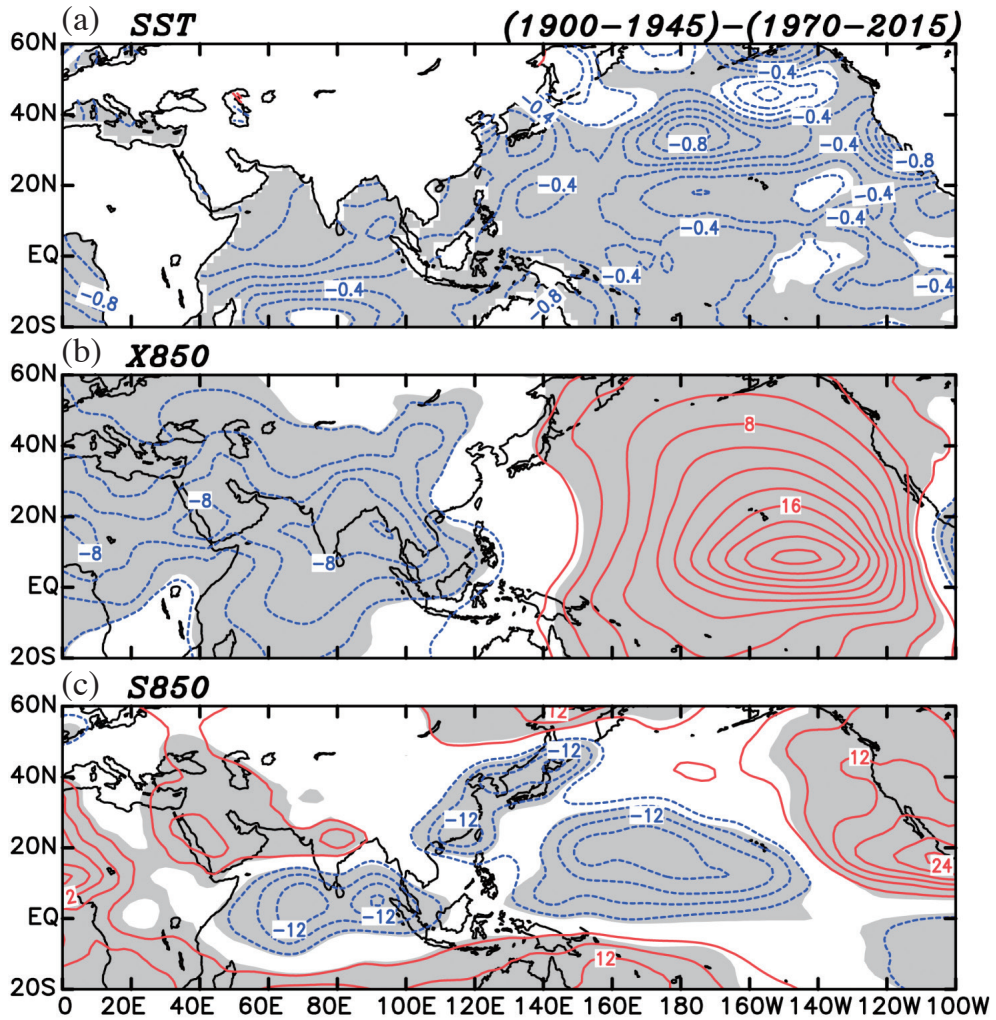

Fig. 4. As in Fig. 2, except for the differences of (a) SST, (b) 850-hPa velocity potential, and (c) 850-hPa streamfunction in July-September of 1900-1945 minus those of 1970-2015. Differences with significance at the 0.10 level of the Student's $t$ test are shaded. Contour intervals are $0.1^{\circ} \mathrm{C}$ in (a), $2 \times 10^{5} \mathrm{~m}^{2} \mathrm{~s}^{-1}$ in (b), and $4 \times 10^{5} \mathrm{~m}^{2} \mathrm{~s}^{-1}$ in (c). The zero contours are suppressed. 
This section presents the climatology fields for the periods of 1900-1945 and 1970-2015 and their differences. Since the two periods reveal a large difference in total typhoon numbers, the period of 1900-1945 will be the focus for the following sections.

\subsection{Modulatory Processes for Typhoon-More and Typhoon-Less Years in 1900-1945}

The annual number of typhoons affecting Taiwan during 1900-1945 showed a clear signal of interannual variability (Fig. 5). The long-term mean and standard deviation for the number of typhoons during this period were 3.11 and 1.54, respectively. Typhoon-more (typhoon-less) years were defined as those with a yearly typhoon number one standard deviation above (below) the average (Table 1). Thus, typhoon-more years included 1903, 1913, 1914, 1923, 1926,1940 , and 1942, with the number of typhoons ranging from 5 to 6 . The typhoon-less years were 1907, 1908, 1915, $1933,1937,1938$, and 1941, with the number of typhoons ranging from 0 to 1 .

Large-scale modulatory processes associated with typhoons affecting Taiwan in July-September during 1900 1945 were examined for typhoon-more and typhoon-less years. The oceanic and atmospheric processes were explored using SST anomalies and lower-tropospheric atmospheric circulation anomalies in terms of X850 and S850 relative to the climatological means during 1900-1945. Composite anomalies of SST, X850, and S850 for the typhoon-more years are shown in Fig. 6. The significant SST anomalies (Fig. 6a) showed warm anomalies elongating the tropical central-eastern Pacific with a maximum center in the central

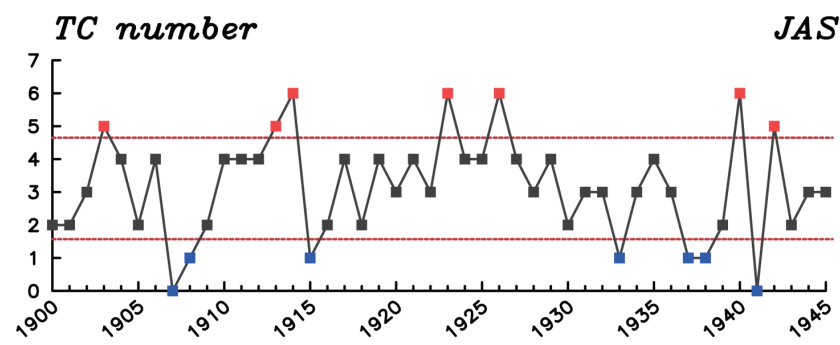

Fig. 5. The time series of the number of typhoons affecting Taiwan in July-September of 1900-1945. The long-term mean is 3.11 and standard deviation is 1.54. The one standard deviation above and below the average are indicated by red dashed lines, respectively.
Pacific and cold anomalies over the tropical western Pacific, similar to those of central Pacific El Niño ( $Y u$ and Kao 2007). A pair of warm and cold anomalies occurred between $30^{\circ} \mathrm{N}$ and $50^{\circ} \mathrm{N}$ with the maximum warming in the western Pacific and a cold center in the eastern Pacific, similar to the positive phase of Pacific Decadal Oscillation (Mantua et al. 1997). These findings suggest the possible modulation of large-scale decadal climate modes on typhoons (Wang and Liu 2016; Yang et al. 2018) and should be explored in further studies.

In terms of SST anomalies, X850 anomalies (Fig. 6b) responded with a divergent center in Maritime Continents and three convergence centers (positive values) over $130^{\circ} \mathrm{W}-160^{\circ} \mathrm{W}$ in the tropical eastern Pacific and over $40^{\circ} \mathrm{N}$ in the northwestern Pacific (Fig. 6b). Through the response of a Matsuno-Gill type (Matsuno 1966; Gill 1980) to tropical forcing illustrated by X850 anomalies, S850 anomalies (Fig. 6c) exhibited a pair of anticyclonic anomalies straddling the Equator to the west of the anomalous convergent center in the Maritime Continents and a pair of cyclonic anomalies to the east. The anomalous anticyclonic circulation around Taiwan tended to drive typhoons over the east of the Philippines moving westward or northward to Taiwan.

For typhoon-more years, there were warm SST anomalies in the tropical eastern Pacific and cold SST anomalies in the Maritime Continent (Fig. 6a). The above tropical forcing induced a northeast-southwesterly anomalous anticyclone overlying Taiwan (Fig. 6c). Typhoon genesis over the $120^{\circ}-130^{\circ} \mathrm{E}, 10^{\circ}-20^{\circ} \mathrm{N}$ region, immediately to the east of the northern Philippines, was facilitated by positive 850-hPa relative vorticity anomalies (Fig. 7a) and ascending (negative) 500-hPa omega anomalies (Fig. 7c) but was

Table 1. The number of typhoons affecting Taiwan during July-September of 1900-1945 for the typhoon-more and typhoon-less years.

\begin{tabular}{cccc}
\hline Classification & Year & Typhoon number & Total (Average) \\
\hline Typhoon-more & 1903 & 5 & $39(5.6)$ \\
& 1913 & 5 & \\
& 1914 & 6 & \\
& 1923 & 6 & \\
& 1926 & 6 & \\
& 1940 & 6 & \\
\hline Typhoon-less & 1907 & 5 & \\
& 1942 & 0 & \\
& 1908 & 1 & \\
& 1933 & 1 & \\
& 1937 & 1 & \\
& 1938 & 1 & \\
& 1941 & 1 & \\
\hline
\end{tabular}



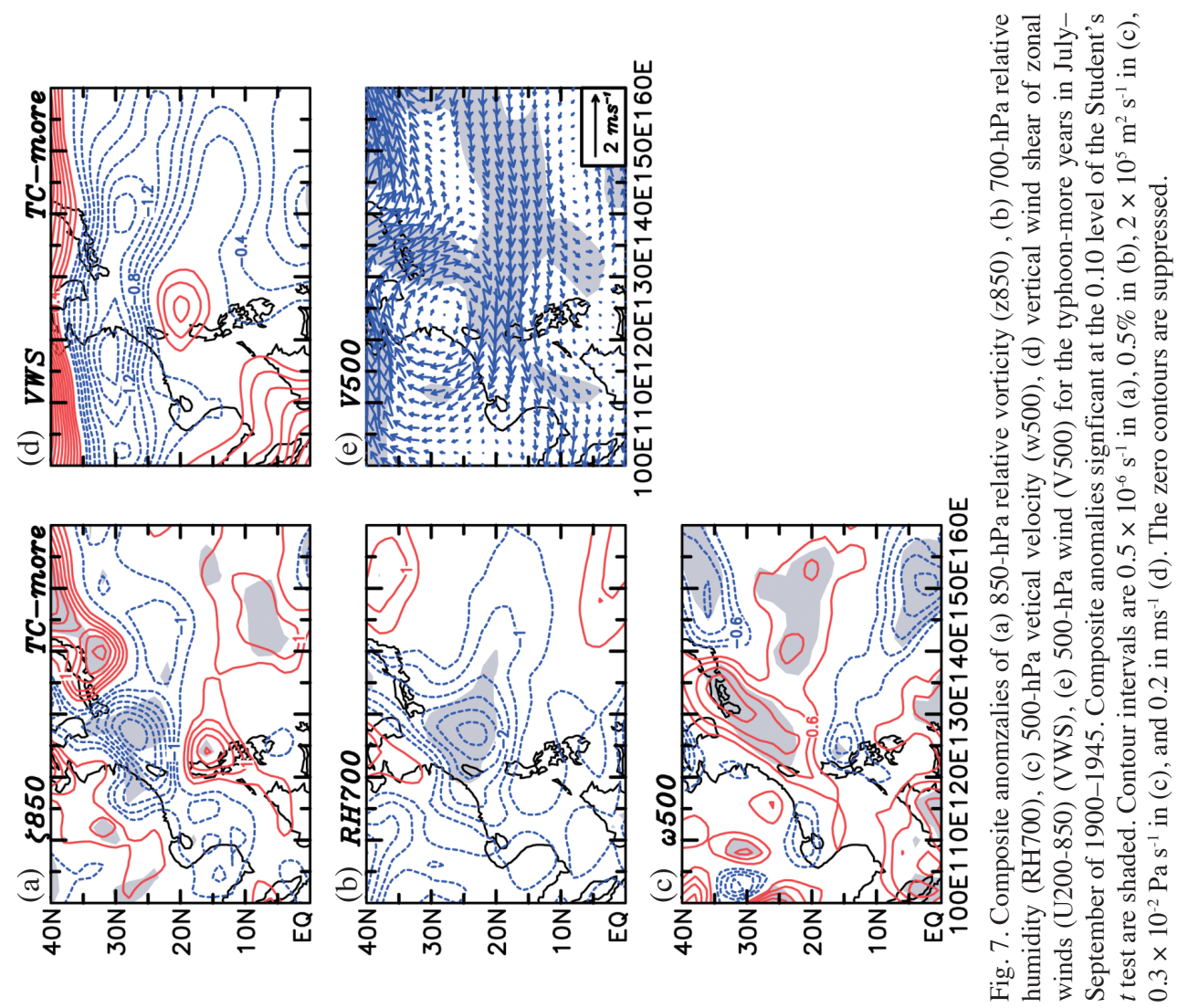

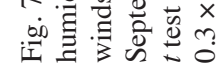
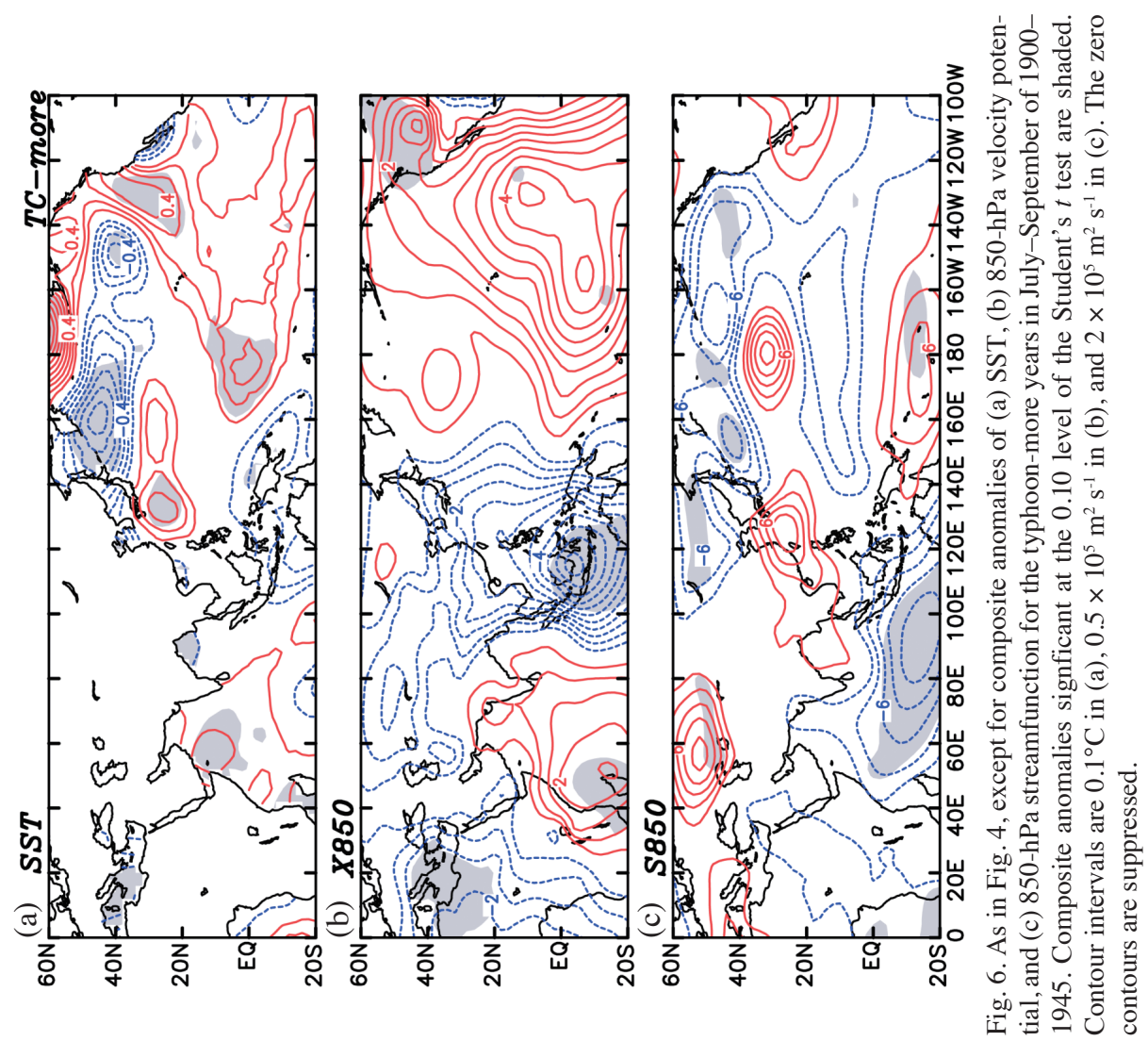
inhibited by 700 -hPa relative humidity (Fig. 7b) and vertical wind shear (Fig. 7d). After formation, typhoons were then driven by anomalous easterly flows to the south of the anomalous anticyclone overlying Taiwan to move toward Taiwan (Fig. 7e), resulting in increased typhoons affecting Taiwan during the typhoon-more years.

For the typhoon-less years, composite anomalies of SST, X850, and S850 are shown in Fig. 8. Cold SST anomalies (Fig. 8a) spread over the tropical central-eastern Pacific with a maximum center in the central Pacific, and warm anomalies over the tropical western Pacific near Maritime Continents, a reversed pattern to those of typhoon-more years. In response to SST anomalies, X850 anomalies (Fig. 8b) exhibited a convergent center to the northeast of the Maritime Continents, and a divergent center over $140^{\circ} \mathrm{W}$ in the tropical eastern Pacific (Fig. 8b). Through the response of a Matsuno-Gill type (Matsuno 1966; Gill 1980) to tropical forcing denoted by X850 anomalies, S850 anomalies (Fig. 8c) demonstrate a pair of cyclonic anomalies straddling the Equator to the west of the anomalous divergent center in the Maritime Continents and a pair of anticyclonic anomalies to the east. The anomalous cyclonic circulation close to Taiwan tended to force typhoons eastwards away from Taiwan.

For the typhoon-less cases, SST anomalies were cold in the tropical eastern Pacific and warm in the Maritime Continent (Fig. 8a). These anomalies forced an anomalous cyclone to the east of Taiwan (Fig. 8c). Underneath this anomalous cyclone, typhoon genesis in the $125^{\circ}-140^{\circ} \mathrm{E}$, $10^{\circ}-20^{\circ} \mathrm{N}$ region, was facilitated by positive $850-\mathrm{hPa}$ relative vorticity anomalies (Fig. 9a), positive $700-\mathrm{hPa}$ relative humidity anomalies (Fig. 9b), ascending (negative) 500-hPa omega anomalies (Fig. 9c), and reduced (negative) vertical wind shear anomalies (Fig. 9d). After formation, typhoons are moving northward toward Japan along the center of the anomalous cyclone, resulting in a reduced chance to approach Taiwan. As such, typhoons affecting Taiwan decrease during the typhoon-less years.

Note that Figs. 7a - $d$ and 9a - $d$ were much more related with the typhoon genesis rather than the typhoon track. Typhoon-more years tended to have two favorable conditions of increased low-level relative vorticity and midlevel vertical velocity anomalies but two unfavorable conditions of decreased low-level relative humidity and increased vertical wind shear anomalies for typhoon genesis (Figs. $7 \mathrm{a}-\mathrm{d}$ ). However, the steering flow (Fig. 7e) played an important role in the movement of typhoons directed toward Taiwan. Typhoon-less years tended to have four favorable conditions of increased low-level relative vorticity, relative humidity, midlevel vertical velocity, and decreased vertical wind shear anomalies for typhoon genesis (Figs. 9a - d). However, the steering flow (Fig. 9e) tended to push typhoons away from Taiwan. For both typhoon-more and typhoon-less years, the steering flow played a critical role in modulating the typhoon numbers affecting Taiwan.

\subsection{ISO Modulations on Typhoon Movements During 1900-1945}

There were six major tracks of typhoons affecting Taiwan during 1900-1945 in the typhoon-more years (Fig. 10). Typhoon tracks 1-5 indicated the westward/northwestward (W/NW) typhoon movement from the east or southeast of Taiwan, and all of them showed a similar movement direction. However, tracks $2-4$ had higher quality because they indicated landfall over Taiwan and had more observation data compared with tracks 1 and 5. Typhoon track 6 exhibited the northward typhoon movement close to Taiwan from the south or southeast of Taiwan, which is a totally different direction from that of tracks $1-5$. Thus, tracks 2-4 and 6 were examined for ISO modulations on typhoon movements for the typhoon-more years. The total sample numbers were 39 and 5 for typhoon-more and typhoon-less years, respectively (Table 1). As a result, the typhoon-more years could be performed for further analysis in different tracks but the sample number for typhoon-less years was too low for the composite analysis of ISO modulation on typhoon tracks.

According to the TCWB report on typhoons affecting Taiwan (Shieh et al. 1998), Day 0 was defined as the first day of the typhoon affecting Taiwan, which refers to the compendium of typhoons affecting Taiwan provided by the TCWB in the website (https://web.archive.org/ web/20170108044417/http://photino.cwb.gov.tw/rdcweb/ lib/clm/tyname.htm). A list of typhoons used for the examination of ISO modulations on movement of typhoons and Day 0 for each typhoon event for tracks 2, 3, 4, and 6 are shown in Table 2.

The composite anomalies of 30-60-day S850 associated with 15 typhoons (Table 2 ) under tracks $2-4$ evolving from 6 days before (Day -6) to 4 days after (Day 4) are shown in Fig. 11. The positions of typhoons in each evolution phase are indicated by solid circles. Composite anomalies significant at the 0.10 level in Student's $t$ test are shaded. Note that typhoon center positions could be traced back at most 4 days before Day 0 due to the limited region of the typhoon track map. In tropical regions, ISO anomalies were quite closely related to tropical convection and could be well illustrated by low-level tropospheric $(850-\mathrm{hPa})$ circulation anomalies rather than mid-level 500-hPa circulation anomalies. For typhoon tracks 2-4, the major features from Day -6 (Fig. 11a) to Day 4 (Fig. 11f) were dominated by a zonally elongated cyclonic anomaly with the strongest center near Taiwan. The locations of the cyclonic center shift from the South China Sea on Day -6 (Fig. 11a), Day -4 (Fig. 11b), and Day -2 (Fig. 11c) to the middle of Taiwan on Day 0 (Fig. 11d), Day 2 (Fig. 11e), and Day 4 (Fig. 11f). This elongated cyclonic anomaly slowly moves northward on Day -4 (Fig. 11b) and Day -2 (Fig. 11c) and continues to move northward with a strengthened intensity on Day 0 
(Fig. 11d) and Day 2 (Fig. 11e), followed by a weakened intensity on Day 4 (Fig. 11f). The typhoon affecting Taiwan tends to form within the 30-60-day cyclonic anomaly to the east/southeast of Taiwan between $120^{\circ} \mathrm{E}$ and $130^{\circ} \mathrm{E}$ on Day -4 (Fig. 11b) and Day -2 (Fig. 11c), then move W/NW inside the anomalous cyclonic center in Taiwan on Day 0 (Fig. 11d), and finally move W/NW to southeastern China. The typhoon affecting Taiwan under tracks 2-4 move along the favorable environment contributed by slowly northward moving and extended 30-60-day anomalous cyclonic circulations around Taiwan. The modulation effects of ISOs on tracks 2-4 during July-September in 1900-1945 were similar to those of La Niña-more-type entrance typhoons in the South China Sea during fall (September-November) in 1960-2010, except the different positions of anomalous cyclonic centers (Tan et al. 2019).

For typhoon track 6, five typhoons (Table 2) were applied, and the major features from Day -6 (Fig. 12a) to Day 4 (Fig. 12f) exhibited an east-west circulation pair of an anomalous cyclone centered to the east of Taiwan and anomalous anticyclonic circulations on its east. This cyclonic anomaly slowly moved northward on Day -4 (Fig. 12b), reached its maximum strength on Day -2 (Fig. 12c), and then decreased from Day 0 (Fig. 12d) to Day 2 (Fig. 12e). The strongest cyclonic center moved to the east of Taiwan from Day -6 (Fig. 12a) to Day 0 (Fig. 12d) and to the middle of Taiwan on Day 2 (Fig. 12e). The typhoons affecting Taiwan under track 6 moved along the favorable environment contributed by slowly northward moving 30-60-day anomalous cyclonic circulations with the strongest center to the east of Taiwan. The modulation effects of ISOs on track 6 during July-September in 1900-1945 were similar to those of recurving migratory typhoons in the South China Sea during July-August and September-October in 19792015 (Chen et al. 2019).

The anomalous ISO cyclone is considered to provide a favorable large-scale environment for typhoons to move in and forward. This process also acts to guide typhoon movement simply via the appearance of an anomalous ISO cyclone. As demonstrated by Chen et al. (2019), there are two major mechanisms for ISO modulations on typhoon movement. One is via strong anomalous flows to drive typhoon movement. In this case, typhoons have to locate in the boundary regions of the circulation anomalies to experience strong steering flows. This case can be found in the typhoons cases with a northward movement shown in Fig. 12 of this study. For the other type, typhoons are located in the middle region of an ISO cyclonic anomaly where steering flows are relatively weak. In this case, typhoons move along with the 30-60-day anomalous cyclone from its southeastern/eastern sections toward its central region. This case can be found in the typhoons cases with a W/NW track shown in Fig. 11 of this study.

\section{CONCLUSIONS}

The typhoon affecting Taiwan was defined as the one with a low-pressure typhoon center that made a landfall in Taiwan or moved near Taiwan and was included in disaster reports during 1900-1945 (Shieh et al. 1998). During this period in Taiwan, the typhoon was recorded to have the maximum sustained wind speed equal to or greater than 34 knots. The annual and monthly typhoon numbers were lower during 1900-1945 than during 1970-2015; however, the monthly percentage of typhoons was comparable between the two periods during the high frequency months of July-September (Fig. 1). Higher typhoon numbers affecting Taiwan during 1970-2015 than during 1900-1945 might be associated with several mechanisms such as warmer ocean temperature (Fig. 3a), intensified western North Pacific subtropical high with westward expansion (Fig. 3c), and better detection techniques during 1970-2015. ISO activity favored typhoons affecting Taiwan both during 1970-2015 (Chen et al. 2018) and 1900-1945 (Figs. 11 - 12).

The typhoon numbers affecting Taiwan during 19001945 (Fig. 5) were obtained from Shieh et al. (1998) developed by Taiwan Central Weather Bureau, different from those after 1960 from the digitalized satellite-supported best-track databases such as JTWC, RSMC, and IBTRACS. Therefore, the typhoon numbers during 1900-1945 and 1970-2015 are not suitable to put together for the analysis of long-term trend or multidecadal variability although the two periods had the distinct difference in temperature change. It is interesting to find more typhoons affecting Taiwan in the warm period of 1970-2015 than the cold period of 1900-1945. However, cautions related to uncertainty about typhoon observations in the pre-satellite 1900-1945 period need to be taken when diagnosing changes of typhoon numbers between these two periods.

The climatological means of SST, X850, and S850 during July-September in 1900-1945 (Fig. 2) exhibited similar patterns but had weaker intensities than those in 1970-2015 (Fig. 3). The intensified western North Pacific subtropical high with a westward expansion contributed the frequency of typhoons affecting Taiwan (Ho et al. 2004; Wu et al. 2005) during 1970-2015 (Fig. 3c) than during 1900-1945 (Fig. 2c). The differences of SST, X850, and S850 during July-September in 1900-1945 minus those in 1970-2015 (Fig. 4) revealed significantly cold SST differences over almost all the entire Pacific Ocean and Indian Ocean, a divergent center in the Bay of Bengal and a convergence center around $140^{\circ} \mathrm{W}$ in the tropical eastern Pacific, a large cyclonic circulation with three minor divided cyclonic centers around Maritime Continents to the north of $10^{\circ} \mathrm{S}$, and an anticyclonic circulation to the south of $10^{\circ} \mathrm{S}$. One of the three divided cyclonic circulations close to Taiwan tended to drive typhoons over the east of the Philippines moving 

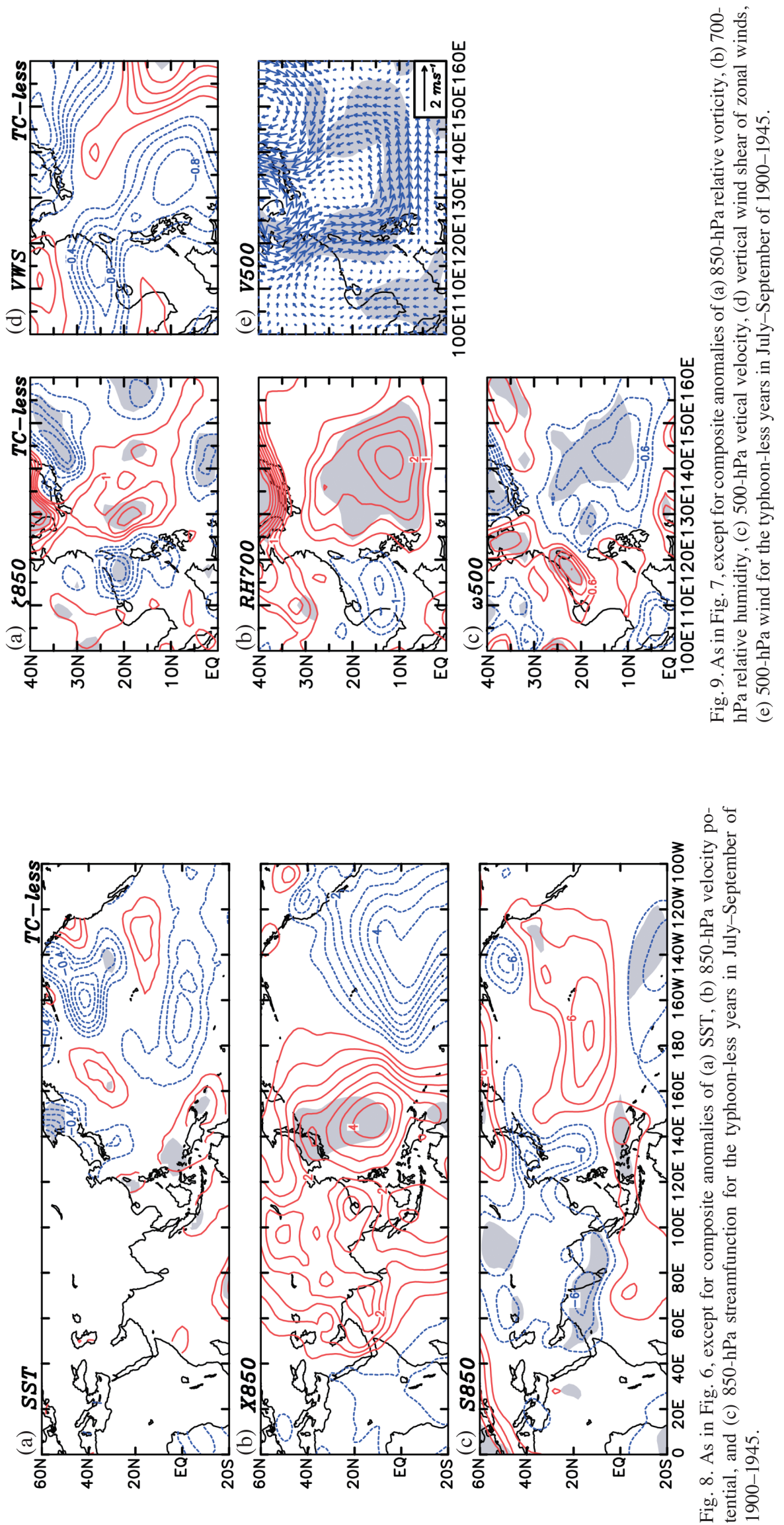


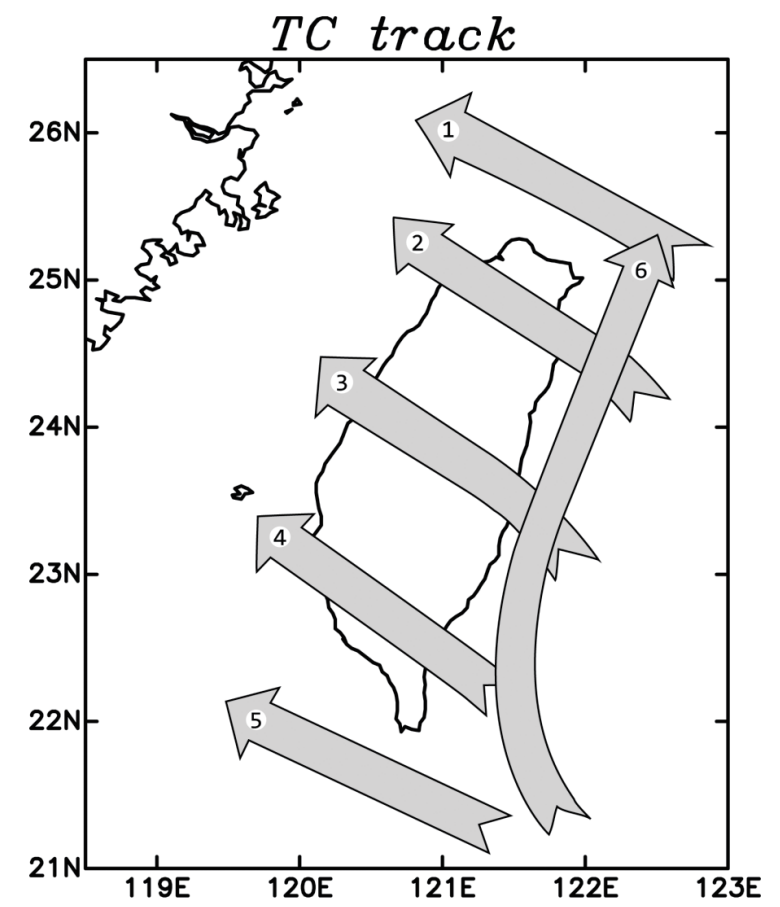

Fig. 10. Typhoon track numbers $1-6$ denote the six major typhoon tracks affecting Taiwan.

Table 2. A list of typhoons used for the examination of ISO modulations on movement of typhoons for tracks 2,3,4, and 6 .

\begin{tabular}{|c|c|c|c|c|c|}
\hline Year & Typhoon name & Date of day 0 & Year & Typhoon name & Date of day 0 \\
\hline \multicolumn{3}{|c|}{ Track $2+3+4$} & \multicolumn{3}{|c|}{ Track 6} \\
\hline 1903 & B019 & $8 / 6$ & 1903 & B018 & $7 / 31$ \\
\hline 1903 & B021 & $8 / 18$ & 1923 & B101 & $8 / 10$ \\
\hline 1903 & B022 & $8 / 30$ & 1926 & B117 & $9 / 15$ \\
\hline 1913 & B058 & $7 / 19$ & 1940 & B161 & $7 / 21$ \\
\hline 1913 & B062 & $9 / 10$ & 1942 & B168 & $7 / 22$ \\
\hline 1914 & B065 & $7 / 7$ & & & \\
\hline 1914 & B066 & $7 / 13$ & & & \\
\hline 1914 & B069 & $9 / 6$ & & & \\
\hline 1926 & B113 & $7 / 31$ & & & \\
\hline 1940 & B160 & $7 / 7$ & & & \\
\hline 1940 & B164 & $8 / 30$ & & & \\
\hline 1940 & B165 & $9 / 30$ & & & \\
\hline 1942 & B166 & $7 / 11$ & & & \\
\hline 1942 & B169 & $8 / 9$ & & & \\
\hline 1942 & B170 & $9 / 12$ & & & \\
\hline
\end{tabular}



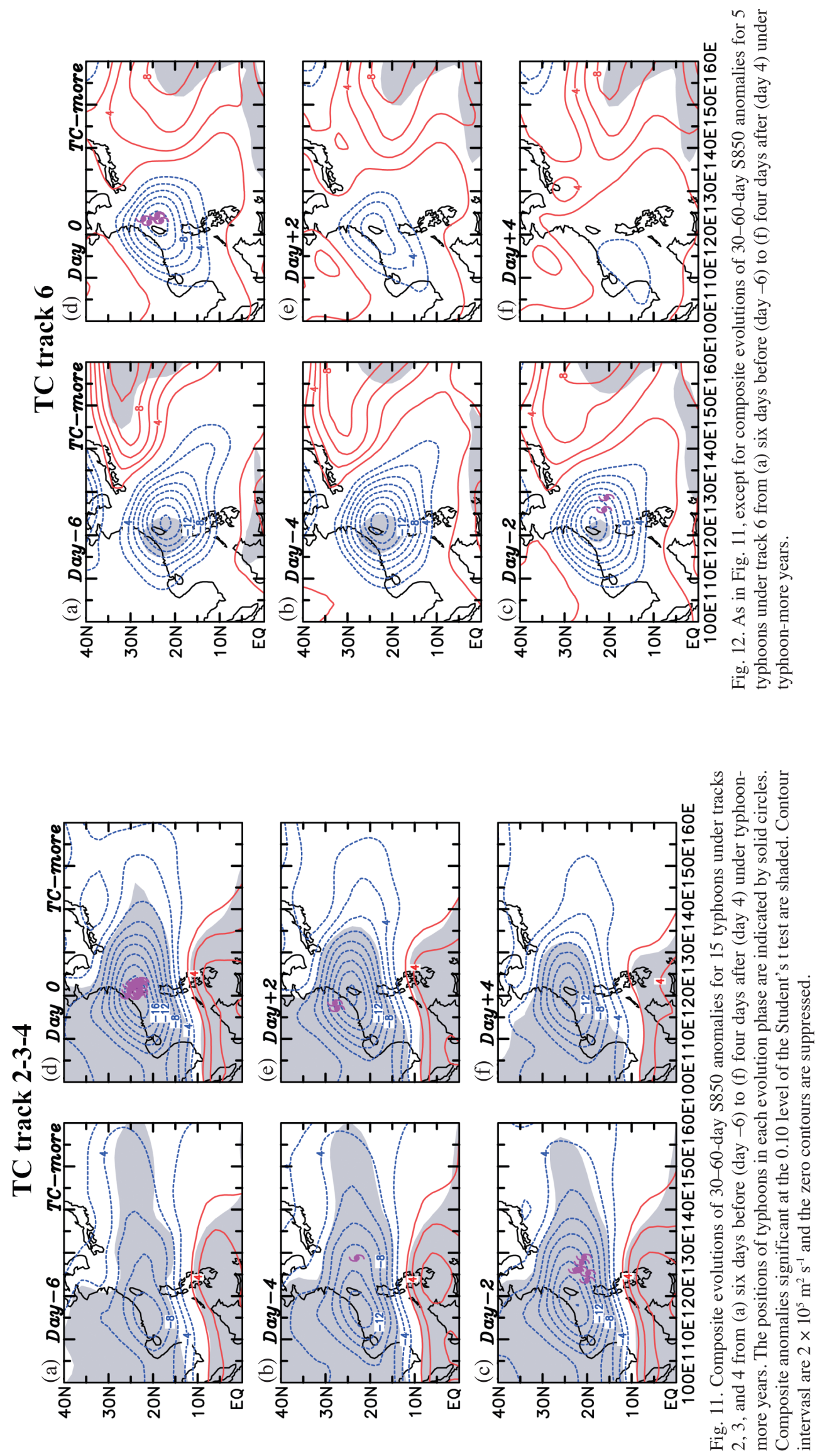
westward or northward toward Taiwan. The lower land-sea contrast in Asia during 1900-1945 than during 1970-2015 should play a role in shaping the complicated pattern of S850 differences.

Typhoon-more (typhoon-less) years during 1900-1945 are defined as the number of typhoons one standard deviation above (below) the average. Schematics of large-scale modulating processes in the typhoon-more and typhoonless years are presented in Fig. 13. For the typhoon-more years, the significant SST patterns were dominated by warm anomalies (red shaded area in Fig. 13a) elongating the tropical central-eastern Pacific with a maximum center in the central Pacific and cold anomalies (blue shaded area in Fig. 13a) over the tropical western Pacific, similar to those of central Pacific El Niño (Yu and Kao 2007). An anticyclonic circulation (red solid lines in Fig. 13a) around Taiwan that responds to a divergent center (blue solid lines in Fig. 13a) in the Maritime Continents tended to drive typhoons over the east of the Philippines moving westward/northwestward to Taiwan. For the typhoon-less years, SST patterns were dominated by cold anomalies (blue shaded area in Fig. 13b) in the tropical central-eastern Pacific with the maximum center in the central Pacific and warm anomalies (red shaded area in Fig. 13b) over the tropical western Pacific near Maritime Continents, a pattern opposite to that observed in the typhoon-more years. A cyclonic circulation (red dashed lines in Fig. 13b) to the east Taiwan that responds to a convergent center (blue dashed lines in Fig. 13b) in the Mari- time Continents tended to force typhoons eastward away from Taiwan.

Typhoon-more years tended to have two favorable conditions of increased low-level relative vorticity and midlevel vertical velocity anomalies but two unfavorable conditions of decreased low-level relative humidity and increased vertical wind shear anomalies for typhoon genesis. However, the eastern/southern steering flow (black arrow in Fig. 13a) played an important role in the movement of typhoons directed toward Taiwan. Typhoon-less years tended to have four favorable conditions of increased low-level relative vorticity, relative humidity, midlevel vertical velocity, and decreased vertical wind shear anomalies for typhoon genesis. However, the western/northern steering flow (black arrow in Fig. 13b) tended to push typhoons away from Taiwan and directed toward Japan.

The anomalous ISO cyclone is considered to provide a favorable large-scale environment for typhoons to move in and forward. This process also acts to guide typhoon movement simply via the appearance of an anomalous ISO cyclone. As demonstrated by Chen et al. (2019), there are two major mechanisms for ISO modulations on typhoon movement. One is via strong anomalous flows to drive typhoon movement. In this case, typhoons have to locate in the boundary regions of the circulation anomalies to experience strong steering flows. This case can be found in the typhoons cases with a northward movement shown in Fig. 12 of this study. For the other type, typhoons are located in the

(a) TC-more

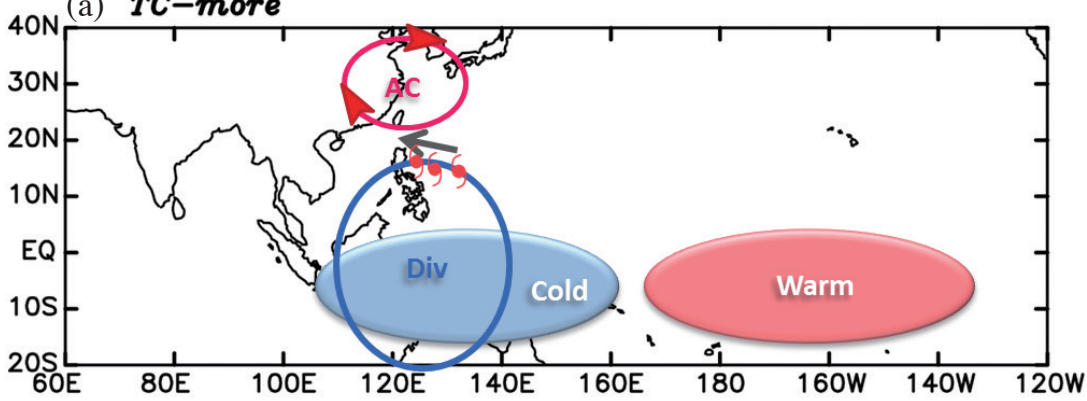

(b) TC-less

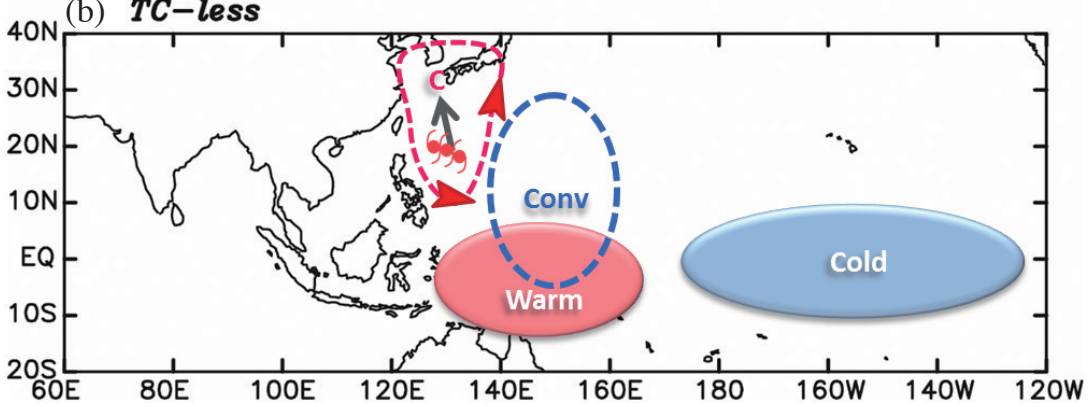

Fig. 13. Schematic diagrams for large-scale modulating processes in the (a) typhoon-more, and (b) typhoon-less years. Positive/negative SST anomalies are marked by "Warm"/"cold" and red/blue shaded areas. Anticyclonic/cyclonic anomalies are represented by "AC"/"C" and red thin solid/dashed lines. Divergence/convergence anomalies are marked by "Div"/"Conv" and blue thin solid/dashed lines. Anomalous steering flows are indicated by black solid arrows. 
middle region of an ISO cyclonic anomaly where steering flows are relatively weak. In this case, typhoons move along with the 30-60-day anomalous cyclone from its southeastern/eastern sections toward its central region. This case can be found in the typhoons cases with a W/NW track shown in Fig. 11 of this study.

Note that the anticyclone/cyclone circulations revealed in the S850 patterns for typhoon-more and typhoon-less years were not statistically significant under $\mathrm{p}<0.10$ (Figs. $6 \mathrm{c}$ and $8 \mathrm{c}$ ) but statistically significant under $\mathrm{p}<0.20$ (not shown). The warm/cold SST patterns derived from Figs. 6a and 8 a also showed a similar behavior (not shown). Since all the associated patterns were statistically significant under $\mathrm{p}$ $<0.20$ which is an acceptable threshold of significance, it is evident that the signals of SSTs and large-scale circulation presented in Fig. 13 are real and meaningful, not random noises. The difference of statistical results of significance might be attributed to less data during 1900-1945 than during 1970-2015 and it is a limitation of our study.

Acknowledgements This study was supported by the Ministry of Science and Technology, Taiwan, under grants of MOST 109-2111-M-415-001 and MOST 110-2111-M-415001, and motivated by Central Weather Bureau under the grant of CWB 1092287C which involves the interdisciplinary research on natural hazards during the Japanese-ruled period. The authors thank Ms. Jia-Chi Chen and Ms. WenTing Huang in the CWB Southern Region Weather Center for their encouragement in the research of historical climate. Comments from two anonymous reviewers are very helpful for improving the quality of this paper.

\section{REFERENCES}

Basconcillo, J. and I.-J. Moon, 2021: Recent increase in the occurrences of Christmas typhoons in the Western North Pacific. Sci. Rep., 11, 7416, doi: 10.1038/ s41598-021-86814-x. [Link]

Bell, R., K. Hodges, P. L. Vidale, J. Strachan, and M. Roberts, 2014: Simulation of the global ENSO-tropical cyclone teleconnection by a high-resolution coupled general circulation model. J. Clim., 27, 6404-6422, doi: 10.1175/JCLI-D-13-00559.1. [Link]

Bruneau, N., S. Wang, and R. Toumi, 2020: Long memory impact of ocean mesoscale temperature anomalies on tropical cyclone size. Geophys. Res. Lett., 47, e2019GL086165, doi: 10.1029/2019GL086165. [Link]

Camargo, S. J. and A. H. Sobel, 2005: Western North Pacific tropical cyclone intensity and ENSO. J. Clim., 18, 2996-3006, doi: 10.1175/JCLI3457.1. [Link]

Camargo, S. J., A. W. Robertson, S. J. Gaffney, P. Smyth, and M. Ghil, 2007: Cluster analysis of typhoon tracks. Part I: General properties. J. Clim., 20, 3635-3653, doi: 10.1175/JCLI4188.1. [Link]
Chen, J.-M. and H.-S. Chen, 2011: Interdecadal variability of summer rainfall in Taiwan associated with tropical cyclones and monsoon. J. Clim., 24, 5786-5798, doi: 10.1175/2011JCLI4043.1. [Link]

Chen, J.-M., T. Li, and C.-F. Shih, 2010: Tropical Cycloneand Monsoon-Induced Rainfall Variability in Taiwan. J. Clim., 23,4107-4120, doi: 10.1175/2010JCLI3355.1. [Link]

Chen, J.-M., H.-S. Chen, and J.-S. Liu, 2013: Coherent interdecadal variability of tropical cyclone rainfall and seasonal rainfall in Taiwan during October. J. Clim., 26, 308-321, doi: 10.1175/JCLI-D-11-00697.1. [Link]

Chen, J.-M., P.-H. Tan, L. Wu, H.-S. Chen, J.-S. Liu, and C.-F. Shih, 2018: Interannual variability of summer tropical cyclone rainfall in the western North Pacific depicted by CFSR and associated large-scale processes and ISO modulations. J. Clim., 31, 1771-1787, doi: 10.1175/JCLI-D-16-0805.1. [Link]

Chen, J.-M., C.-H. Wu, J. Gao, P.-H. Chung, and C.-H. Sui, 2019: Migratory tropical cyclones in the South China Sea modulated by intraseasonal oscillations and climatological circulations. J. Clim., 32, 6445-6466, doi: 10.1175/JCLI-D-18-0824.1. [Link]

Chen, J.-M., P.-H. Lin, C.-H. Wu, and C.-H. Sui, 2020: Track variability of South China Sea-formed tropical cyclones modulated by seasonal and intraseasonal circulations. Terr. Atmos. Ocean. Sci., 31, 239-259, doi: 10.3319/TAO.2019.11.07.02. [Link]

Chen, T.-C. and J.-M. Chen, 1995: An observational study of the South China Sea monsoon during the 1979 summer: Onset and life cycle. Mon. Weather Rev., 123, 2295 2318, doi: 10.1175/1520-0493(1995)123<2295:AOSO TS $>2.0 . C O ; 2$. [Link $]$

Chen, T.-C., M.-C. Yen, and S.-P. Weng, 2000: Interaction between the summer monsoons in East Asia and the South China Sea: Intraseasonal monsoon modes. J. Atmos. Sci., 57, 1373-1392, doi: 10.1175/1520-0469(2000)057<1373:IBTSMI>2.0. $\mathrm{CO} ; 2$. [Link $]$

Chia, H. H. and C. F. Ropelewski, 2002: The interannual variability in the genesis location of tropical cyclones in the northwest Pacific. J. Clim., 15, 2934-2944, doi: 10.1175/1520-0442(2002)015<2934:TIVITG>2.0. $\mathrm{CO} ; 2$. [Link]

Chin, P. C., 1958: Tropical Cyclones in the Western Pacific and China Sea Area from 1884 to 1953, Royal Observatory, Hong Kong, 85 pp.

Chu, P.-S., X. Zhao, C.-H. Ho, H.-S. Kim, M.-M. Lu, and J.-H. Kim, 2010: Bayesian forecasting of seasonal typhoon activity: A track-pattern-oriented categorization approach. J. Clim., 23, 6654-6668, doi: 10.1175/2010JCLI3710.1. [Link]

Chu, P.-S., J.-H. Kim, and Y. R. Chen, 2012: Have steering flows in the western North Pacific and the South 
China Sea changed over the last 50 years? Geophys. Res. Lett., 39, L10704, doi: 10.1029/2012GL051709. [Link]

Colbert, A. J., B. J. Soden, and B. P. Kirtman, 2015: The Impact of Natural and Anthropogenic Climate Change on Western North Pacific Tropical Cyclone Tracks. J. Clim., 28, 1806-1823, doi: 10.1175/JCLID-14-00100.1. [Link]

Compo, G. P., J. S. Whitaker, P. D. Sardeshmukh, N. Matsui, R. J. Allan, X. Yin, B. E. Gleason, R. S. Vose, G. Rutledge, P. Bessemoulin, S. Brönnimann, M. Brunet, R. I. Crouthamel, A. N. Grant, P. Y. Groisman, P. D. Jones, M. C. Kruk, A. C. Kruger, G. J. Marshall, M. Maugeri, H. Y. Mok, Ø. Nordli, T. F. Ross, R. M. Trigo, X. L. Wang, S. D. Woodruff, and S. J. Worley, 2011: The Twentieth Century Reanalysis Project. Q.J.R. Meteorol. Soc., 137, 1-28, doi: 10.1002/qj.776. [Link]

DeMaria, M., J. A. Knaff, and B. H. Connell, 2001: A tropical cyclone genesis parameter for the tropical Atlantic. Weather Forecast., 16, 219-233, doi: 10.1175/1520-0434(2001)016<0219:ATCGPF>2.0. CO;2. [Link]

Ding, Y., 2007: The variability of the Asian summer monsoon. J. Meteorol. Soc. Jpn., 85B, 21-54, doi: 10.2151/ jmsj.85B.21. [Link]

Emanuel, K., 2008: The hurricane-climate connection. Bull. Amer. Meteorol. Soc., 89, ES10-ES20, doi: 10.1175/BAMS-89-5-Emanuel. [Link]

Fudeyasu, H., S. Iizuka, and T. Matsuura, 2006: Impact of ENSO on landfall characteristics of tropical cyclones over the western North Pacific during the summer monsoon season. Geophys. Res. Lett., 33, L21815, doi: 10.1029/2006GL027449. [Link]

Gill, A. E., 1980: Some simple solutions for heat-induced tropical circulation. Q. J. R. Meteorol. Soc., 106, 447462, doi: 10.1002/qj.49710644905. [Link]

Gray, W. M., 1968: Global view of the origin of tropical disturbances and storms. Mon. Weather Rev., 96, 669700, doi: 10.1175/1520-0493(1968)096<0669:GVOT OO>2.0.CO;2. [Link]

Gray, W. M., 1998: The formation of tropical cyclones. Meteorol. Atmos. Phys., 67, 37-69, doi: 10.1007/ BF01277501. [Link]

Hartmann, D. L., M. L. Michelsen, and S. A. Klein, 1992: Seasonal variations of tropical intraseasonal oscillations: A 20-25-day oscillation in the western Pacific. J. Atmos. Sci., 49, 1277-1289, doi: 10.1175/1520-0469(1992)049<1277:SVOTIO>2.0. $\mathrm{CO} ; 2$. [Link]

Ho, C.-H., J.-J. Baik, J.-H. Kim, D.-Y. Gong, and C.H. Sui, 2004: Interdecadal changes in summertime typhoon tracks. J. Clim., 17, 1767-1776, doi: 10.1175/1520-0442(2004)017<1767:ICISTT>2.0. CO;2. [Link]
Hsu, C.-H., 1973: The typhoon track map in the past 80 years. The Research Report of National Science Council, Executive Yuan, Taiwan, 1-573.

Kim, H.-M., P. J. Webster, and J. A. Curry, 2011: Modulation of North Pacific Tropical Cyclone Activity by Three Phases of ENSO. J. Clim., 24, 1839-1849, doi: 10.1175/2010JCLI3939.1. [Link]

Kim, H.-M., M.-I. Lee, P. J. Webster, D. Kim, and J. H. Yoo, 2013: A physical basis for the probabilistic prediction of the accumulated tropical cyclone kinetic energy in the western North Pacific. J. Clim., 26, 7981-7991, doi: 10.1175/JCLI-D-12-00679.1. [Link]

Kim, H.-S., C.-H. Ho, J.-H. Kim, and P.-S. Chu, 2012: Track-pattern-based model for seasonal prediction of tropical cyclone activity in the western North Pacific. J. Clim., 25, 4660-4678, doi: 10.1175/JCLID-11-00236.1. [Link]

Ko, K.-C. and H.-H. Hsu, 2009: ISO modulation on the submonthly wave pattern and recurving tropical cyclones in the tropical western North Pacific. J. Clim., 22, 582599, doi: 10.1175/2008JCLI2282.1. [Link]

Kubota, H. and B. Wang, 2009: How much do tropical cyclones affect seasonal and interannual rainfall variability over the western North Pacific? J. Clim., 22, 54955510, doi: 10.1175/2009JCLI2646.1. [Link]

Lander, M. A., 1994: An exploratory analysis of the relationship between tropical storm formation in the western North Pacific and ENSO. Mon. Weather Rev., 122, 636-651, doi: 10.1175/1520-0493(1994)122<0636:AE AOTR $>2.0 . C O ; 2$. [Link]

Lee, C.-S., R. Edson, and W. M. Gray, 1989: Some largescale characteristics associated with tropical cyclone development in the north Indian Ocean during FGGE. Mon. Weather Rev., 117, 407-426, doi: 10.1175/1520-0493(1989)117<0407:SLSCAW >2.0. CO;2. [Link]

Li, R. C. Y. and W. Zhou, 2013: Modulation of western North Pacific tropical cyclone activity by the ISO. Part II: Tracks and landfalls. J. Clim., 26, 2919-2930, doi: 10.1175/JCLI-D-12-00211.1. [Link]

Liebmann, B., H. H. Hendon, and J. D. Glick, 1994: The relationship between tropical cyclones of the western $\mathrm{Pa}$ cific and Indian Oceans and the Madden-Julian oscillation. J. Meteorol. Soc. Jpn., 72, 401-412, doi: 10.2151/ jmsj1965.72.3_401. [Link]

Mantua, N. J., S. R. Hare, Y. Zhang, J. M. Wallace, and R. C. Francis, 1997: A Pacific interdecadal climate oscillation with impacts on salmon production. Bull. Amer. Meteorol. Soc., 78, 1069-1080, doi: 10.1175/1520-0477(1997)078<1069:APICOW>2.0. $\mathrm{CO} ; 2$. [Link]

Matsuno, T., 1966: Quasi-geostrophic motions in the equatorial area. J. Meteorol. Soc. Jpn., 44, 25-43, doi: 10.2151/jmsj1965.44.1_25. [Link] 
McTaggart-Cowan, R., E. L. Davies, J. G. Fairman, T. J. Galarneau, and D. M. Schultz, 2015: Revisiting the $26.5^{\circ} \mathrm{C}$ Sea Surface Temperature Threshold for Tropical Cyclone Development. Bull. Amer. Meteorol. Soc., 96, 1929-1943, doi: 10.1175/BAMS-D-13-00254.1. [Link]

Shieh, S.-L., S.-T. Wang, M.-D. Cheng, and T.-C. Yeh, 1998: Tropical Cyclone Tracks over Taiwan from 1897 to 1996 and Their Applications, CWB86-1M-01, Central Weather Bureau, Taipei, Taiwan, 497 pp.

Tan, P.-H., J.-Y. Tu, L. Wu, H.-S. Chen, and J.-M. Chen, 2019: Asymmetric relationships between El NiñoSouthern Oscillation and entrance tropical cyclones in the South China Sea during fall. Int. J. Climatol., 39, 1872-1888, doi: 10.1002/joc.5921. [Link]

Tsou, C.-H., P.-Y. Huang, C.-Y. Tu, C.-T. Chen, T.-P. Tzeng, and C.-T. Cheng, 2016: Present simulation and future typhoon activity projection over western North Pacific and Taiwan/East Coast of China in 20-km HiRAM climate model. Terr. Atmos. Ocean. Sci., 27, 687-703, doi: 10.3319/TAO.2016.06.13.04. [Link]

Tu, J.-Y. and J.-M. Chen, 2019: Large-scale indices for assessing typhoon activity around Taiwan. Int. J. Climatol., 39, 921-933, doi: 10.1002/joc.5852. [Link]

Tu, J.-Y., C. Chou, and P.-S. Chu, 2009: The abrupt shift of typhoon activity in the vicinity of Taiwan and its association with western North Pacific-East Asian climate change. J. Clim., 22, 3617-3628, doi: 10.1175/2009JCLI2411.1. [Link]

Wang, B. and J. C. L. Chan, 2002: How strong ENSO events affect tropical storm activity over the western North Pacific. J. Clim., 15, 1643-1658, doi: 10.1175/1520-0442(2002)015<1643:HSEEAT>2.0. CO;2. [Link]

Wang, B. and H. Lin, 2002: Rainy season of the AsianPacific summer monsoon. J. Clim., 15, 386-398, doi: 10.1175/1520-0442(2002)015<0386:RSOTAP>2.0. CO;2. [Link]
Wang, L. and G. Chen, 2018: Relationship between South China Sea summer monsoon onset and landfalling tropical cyclone frequency in China. Int. J. Climatol., 38, 3209-3214, doi: 10.1002/joc.5485. [Link]

Wang, S.-D., 1992: Integrated research of typhoon track, intensity, structure, wind and rain. The Research Report of National Science Council, Executive Yuan, Taiwan, $1-285$.

Wang, X. and H. Liu, 2016: PDO modulation of ENSO effect on tropical cyclone rapid intensification in the western North Pacific. Clim. Dyn., 46, 15-28, doi: 10.1007/s00382-015-2563-8. [Link]

Wu, L. and B. Wang, 2004: Assessing impacts of global warming on tropical cyclone tracks. J. Clim., 17, 16861698, doi: 10.1175/1520-0442(2004)017<1686:AIOG$\mathrm{WO}>2.0 . \mathrm{CO} ; 2$. [Link $]$

Wu, L., B. Wang, and S. Geng, 2005: Growing typhoon influence on East Asia. Geophys. Res. Lett., 32, L18703, doi: 10.1029/2005GL022937. [Link]

Yang, L., S. Chen, C. Wang, D. Wang, and X. Wang, 2018: Potential impact of the Pacific Decadal Oscillation and sea surface temperature in the tropical Indian OceanWestern Pacific on the variability of typhoon landfall on the China coast. Clim. Dyn., 51, 2695-2705, doi: 10.1007/s00382-017-4037-7. [Link]

Yu, J.-Y. and H.-Y. Kao, 2007: Decadal changes of ENSO persistence barrier in SST and ocean heat content indices: 1958-2001. J. Geophys. Res., 112, D13106, doi: 10.1029/2006JD007654. [Link]

Zhan, R., Y. Wang, and X. Lei, 2011: Contributions of ENSO and east Indian Ocean SSTA to the interannual variability of Northwest Pacific tropical cyclone frequency. J. Clim., 24, 509-521, doi: 10.1175/2010JCLI3808.1. [Link]

Zhao, H., L. Wu, and W. Zhou, 2011: Interannual changes of tropical cyclone intensity in the western North Pacific. J. Meteorol. Soc.Jpn., 89, 243-253, doi: 10.2151/ jmsj.2011-305. [Link] 